\title{
Paraolimpiada - parasportowcy - paraludzie? Sport osób z niepełnosprawnością w Internecie
}

Tematyka artykułu wynika z zainteresowania sportem, a także z ciekawości „świata” osób z niepełnosprawnością oraz tego, jak kreuje się on w osobach niezwiązanych z pedagogiką specjalną oraz tym, jak przeplatanie tych „światów” wpływać może na funkcjonowanie osób z niepełnosprawnością $\mathrm{w}$ społeczeństwie. Przestrzeń moich badań wiąże się z chęcią sprawdzenia się w czymś nowym - badaniach Internetu oraz z tym, że Internet jest przestrzenią mi i moim rówieśnikom dobrze znaną, jednak z innego punktu widzenia. Celem tych badań jest przybliżenie treści umieszczonych w Internecie, które dotyczą sportu oraz sportowców z niepełnosprawnością, określenie miejsca zjawiska sportu osób z niepełnosprawnością w Internecie oraz poznanie sposobu przedstawiania niepełnosprawnych sportowców w sieci. Pierwszą część artykułu stanowi analiza literatury przedmiotu na temat niepełnosprawności, drugą - rozważania dotyczące sportu osób z niepełnosprawnością. W trzeciej części przedstawione są metodologiczne podstawy pracy. Kolejne to analiza i interpretacja materiału.

Słowa kluczowe: sport, sportowcy niepełnosprawność, paraolimpiada, Internet

\section{Paralympic, para-sportsmem, para-people? Sport of disabled people in the Internet}

The subject of this article arises from my interest in sports and also from a curiosity of a reality of disabled people's life. I likewise wanted to explore the point of view of people who has no connection with special pedagogy on that matter and it's affect on disabled people's lives. My only knowledge about disabled sportsmen came from the film „Murderball” and this paper is my attempt to gain more information about sport of disabled people and their image that is created in abled people's mind. I have chosen the Internet as a space for my research because it is an area that is commonly known by my peers and me, but we know it from a different perspective. The main aim of my research is to show the information that can be found on the Internet, which are connected with the sport of disabled people, disabled sportsmen, the space that they take on the Internet. I want to recognize the way that these information are shown on the Internet. First part of the article is the analysis of the source literature about disability, the second one is my debate regarding the sports of disabled people. The third part is about the methodological base of the article and the last part - analysis and interpretation of the empiric material.

Keywords: sport, sportsmen, disability, paralympic, Internet 
Odpowiedź na pytanie: „Czym w zasadzie owa niepełnosprawność jest?” przysparza wiele problemów nawet pedagogom specjalnym. Przede wszystkim dlatego, iż jest ona pojęciem wielopłaszczyznowym i dotyczy wielu wymiarów, niczym soczewka skupia aktualnie obowiązujące społeczno-kulturowe normy i standardy, a także obejmuje różnorakie funkcjonalne ograniczenia osób jej doświadczających [Kirenko 2010].

WHO opisuje niepełnosprawność, jako brak zdolności, bądź jej ograniczenie do wykonywania czynności w zakresie uznanym za normalny dla człowieka oraz w sposób, który za taki się uznaje, co wynika z uszkodzenia funkcji organizmu. Jest to jedno z trzech uwarunkowań, jakie znajdują się w Międzynarodowej Klasyfikacji Funkcjonowania, Niepełnosprawności i Zdrowia (ICF) przyjętej przez WHO. Obok niej jest uszkodzenie, czy też niesprawność, czyli każda nieprawidłowość w funkcjonowaniu organizmu lub jego budowie, lub utrata sprawności pod względem fizycznym oraz psychologicznym. Trzecim z pojęć jest upośledzenie - niepełnosprawność społeczna, czyli ograniczenie w zakresie pełnienia ról społecznych oraz w społecznej integracji (Kulesza, Marcinkowska 2004). Mówiąc o niepełnosprawności mówi się o relacjach miedzy człowiekiem a otaczającym go środowiskiem, a Światowa Organizacja Zdrowia podkreśla trzy kluczowe aspekty, które stanowić mają główne wymiary tejże problematyki wspomniane powyżej, to jest: uszkodzenie (impairment), niepełnosprawność (disability) oraz upośledzenie (handicap). Do takiego ujęcia niepełnej sprawności przyczyniła się koncepcja niepełnosprawności, jako procesu dynamicznego, składającego się z następujących stopni: patologia - pojawienie się stanu fizycznego, uszkodzenie - utrata właściwej struktury, ograniczenie funkcjonowania, niepełnosprawność - ograniczenie możliwości pełnienia ról społecznych [Kirenko 2006].

Poprzez tę definicję niepełnosprawności zaproponowanej przez WHO, złożonej z trzech komponentów, opartej na owej koncepcji oraz widać wyraźnie proces kształtowania się tego terminu, przechodząc płynnie z modelu medycznego - uszkodzenia, poprzez modele funkcjonalne - niepełnosprawność (funkcjonalna), aż po społeczne postrzeganie niepełnosprawności - upośledzenie (społeczne) oraz wielki wpływ krytyki i ewolucji owych modeli znanych doskonale pedagogom specjalnym.

Model medyczny -istotny przede wszystkim z punktu widzenia lekarskiego, $\mathrm{w}$ pewnym sensie formalnego oraz prawnego. Funkcjonalny, skupia się natomiast na utrudnieniach, jakich należy się pozbyć, czy też w jak największym stopniu zniwelować poprzez odpowiednią rehabilitację, rozumianą szeroko, to jest zarówno ruchową, jak i zawodową i społeczną, nakierowaną na osobę niepełnosprawną [Wiliński 2010]. Najbliższa pedagogice specjalnej, na obecnym etapie jej rozwoju jest jednak interpretacja społeczna, w której zwraca się szczególną rolę na społeczeństwo, które tak naprawdę samo nie tylko definiuje niepełnospraw- 
ność, ale też dzieli na pełno- i niepełnosprawne osoby poprzez owe bariery i trudności stawiane $\mathrm{w}$ życiu codziennym, a których zniwelowanie poprzez swoistą rehabilitację rozumianą równie szeroko, ale nakierowaną na niedostosowany, otaczający nas świat, oznaczałoby inkluzję osób z niepełnosprawnością, do czego się dąży [Papiernik 2011]. Podejście takie sprawia również warunki do holistycznego i indywidualnego poznania osoby, która w modelu medycznym ukrywa się gdzieś za niepełnosprawnością- deficytem, deformacją, a w modelu funkcjonalnym patrzy się na nią przez pryzmat niedostosowania do funkcjonowania $\mathrm{w} \dot{z} y-$ ciu codziennym.

Nie oznacza to jednak, że należałoby w XXI wieku odrzucać dwa pozostałe modele, a zaczerpnąc $\mathrm{z}$ nich to, co wydaje się najlepsze w drodze do jak najdoskonalszego uprawiania pedagogiki specjalnej. Obecnie podkreśla się jednak przede wszystkim znaczenie wpływu świata zewnętrznego na niepełnosprawność, co zawiera się doskonale $\mathrm{w}$ stwierdzeniu, iż osoba z ogromnym nawet potencjałem możliwości, może zostać upośledzona $\mathrm{w}$ stopniu głębokim przez społeczeństwo, w którym wszystko zaprojektowane jest względem normy [Sadowska 2005].

\section{Sport osób z niepełnosprawnością - niby-sportowcy?}

"Sport to zdrowie!" - to hasło, które zna każdy z nas i które towarzyszy nam od najmłodszych lat do późnej starości. Wyraża ono przekonanie o pozytywnym wpływie aktywności fizycznej na zdrowie człowieka. Według Centrum Badania Opinii Społecznej (CBOS) w 2013 r. aktywność fizyczną w ciągu poprzedzającego roku deklarowało 66\% Polaków, z czego $40 \%$ podejmowało się tej aktywności regularnie (www.cbos.pl). Wyniki badań nad aktywnością Polaków ze schyłku roku 2017, przeprowadzone przez Santander Consumer Bank ukazują, że liczba ta zwiększa się już do niemal 70\%, a 40\% Polaków deklaruje, że zachęca swoich najbliższych do uprawiania sportu (www.polskatimes.pl). Tendencję zwyżkową można jednak zauważyć nie przyglądając się wcale liczbom, ale wychodząc na ulicę.

Sport, w kontekście niepełnosprawności może być kojarzony z rehabilitacją ruchową. Tradycje sportu właśnie $w$ procesie rehabilitacji sięgają okresu po II wojnie światowej. To podczas rehabilitacji wielu tysięcy poszkodowanych zwrócono uwagę na to, jaki ogromny wpływ na poprawę funkcjonowania ma w jej procesie sport. w Wielkiej Brytanii oraz w Stanach Zjednoczonych Ameryki Północnej kładziono nacisk na funkcję leczniczą i zdrowotną zajęć rehabilitacyjnych, ale też na ich walory integracyjne. Stąd też, poza sportem w rehabilitacji rozumianym 
czysto fizycznie, jako swego rodzaju „rozruch” organizmu pojawiły się w niej elementy sportowego zacięcia i rywalizacji, które dopełniły zakres jej oddziaływań [Koper 2013]. Tak silne zaowocowanie owych rezultatów przyczyniło się do ukształtowania swego rodzaju podwalin pod nowoczesne zajęcia rehabilitacyjne, a także pod sport rekreacyjny oraz wyczynowy osób z niepełnosprawnością [Pawlikowska 2016].

Szczególną uwagę jednak skupię na sporcie też zawodowym z racji tego, że to głównie on będzie brany pod uwagę $w$ badaniach przeprowadzonych $w$ ramach tej pracy. Sport wyczynowy przyczynia się do zatarcia granicy między niepełnosprawnymi a społeczeństwem, a także wpływa na zmniejszenie dyskryminacji, jednak stanowiący liczną grupę członków różnych sportowych klubów osoby niepełnosprawne mają zgoła inny punkt widzenia traktując swoją obecność w owych klubach i aktywny w nich udział po prostu, jako rywalizację sportową [Pawlikowska 2016]. Wydaje się więc, że pobudki do uprawiania sportu w przypadku sportowców niepełnosprawnych są tożsame do tych, którymi kierują się pełnosprawni sportowcy. Ze sportem nieodłącznie idzie w parze ciało oraz kontrola nad nim. Wszechobecnie panuje kult ciała, który również kształtuje w znacznym stopniu samoocenę niepełnosprawnych, przede wszystkim tych, których dysfunkcje widoczne są na pierwszy rzut oka, jednak ma on też wpływ na pozostałą część społeczeństwa, w mniejszym lub większym stopniu, w zależności od naszych wewnętrznych, psychicznych uwarunkowań. Wynika z tego, że część osób, tak niepełno-, jak i pełnosprawnych, rozpoczyna przygodę ze sportem właśnie dlatego, aby wykonać próbę podążania za kultem idealnego ciała i przejęcia kontroli nad swoim własnym $w$ celu podwyższenia własnej samooceny $i$ atrakcyjności.

Jeżeli mowa o sporcie osób niepełnosprawnych, nie da ominąć się tematu Igrzysk Paraolimpijskich. Podczas trwających równolegle Igrzysk Olimpijskich w Londynie w roku 1948 odbyły się eksperymentalnie, w szpitalu, z inicjatywy Ludwiga Guttmanna, pierwsze w historii zawody łucznicze, a dwanaście lat później, również z jego inicjatywy odbyły się pierwsze Letnie Igrzyska Paraolimpijskie, w których uczestniczyły 23 kraje reprezentowane przez 400 sportowców [Koper 2013]. Obecnie w Igrzyskach tych bierze udział już ponad dziesięć razy więcej sportowców, którzy rywalizują ze sobą w ponad pięciuset konkurencjach z 22 dyscyplin - podczas ostatniej edycji w roku 2016 pojawily się dwie dodatkowe: kajakarstwo i triathlon, poza nimi są to między innymi: lekkoatletyka, kolarstwo, łucznictwo, boccia, rugby na wózkach, tenis na wózkach (www.paralympic. org/rio-2016). Letnie Igrzyska Paraolimpijskie mają swój zimowy odpowiednik, a najbliższe Zimowe Igrzyska Paraolimpijskie odbędą się (czas przyszły w związku $\mathrm{z}$ tym, jak rozłożone jest $\mathrm{w}$ czasie pisanie pracy) $\mathrm{w}$ terminie 9-8 marca $2018 \mathrm{r}$. w Pyeong Chang (www.paralympic.org). Weźmie w nich udział 670 zawodni- 
ków, którzy zmierzą się w osiemdziesięciu konkurencjach z sześciu dyscyplin: narciarstwo alpejskie, narciarstwo biegowe, biathlon, hokej na sledgah [sledżach] (sanki ze stalowymi łyżwami - www.pzsnstart.eu/hokej-na-sledgach), curling, para snowboard (www.paralympic.org.pl).

Idee olimpijskie w sporcie uprawianym przez osoby z niepełnosprawnością pojawiają się nie tylko w ruchu paraolimpijskim, ale także przejawiają się poprzez Olimpiady Specjalne. Zawody te mają charakter bardziej humanitarny niż stricte sportowy, a sport uprawiany podczas nich sfokusowany jest bardziej na rozwoju osób z niepełnosprawnością intelektualną. Potwierdzają to słowa przysięgi, którą wypowiadają co roku sportowcy podczas ceremonii otwarcia: Będę się starat zwyciężyć, lecz jeżeli to będzie niemożliwe, godnie pokonam samego siebie [Maszczak 1998]. Nie można odmówić promowania szacunku dla człowieka w Igrzyskach Olimpijskich oraz Paraolimpijskich, jednak podczas imprez sportowych ruchu Olimpiad Specjalnych stoi on wręcz na piedestale i dostarczany jest przez radość, która płynąć ma w samym już uczestnictwie w zawodach. W Olimpiadach Specjalnych biorą udział także osoby z niepełnosprawnością intelektualną.

Igrzyska Olimpijskie, w których udział biorą sportowcy z niepełnosprawnością, nazywane są Igrzyskami Paraolimpijskimi bądź też skrótowo Paraolimpiadą (jako odpowiednik Olimpiady); sportowcy występujący na nich to paraolimpijczycy. Przedrostek „para-,, i jego znaczenie pełnią przede wszystkim funkcję językową, a jego definicja prezentuje się następująco: „pierwszy człon wyrazów złożonych, oznaczający: niby, prawie, wyrażający podobieństwo do tego, co jest określane drugą częścią złożenia" [Drabik i in. 2017]. Tym samym, można zdefiniować Igrzyska Paraolimpijskie, jako Igrzyska Prawie Olimpijskie; paraolimpijczyka, jako pseudo olimpijczyka, co kojarzy się z kimś kto do końca jednak olimpijczykiem nie jest; wreszcie samego sportowca z niepełnosprawnością, nazwanego parasportowcem, jako niby - sportowca, czyli kogoś do sportowca tylko podobnego.

\section{Założenia metodologiczne badań własnych}

Przedmiotem badań w niniejszej pracy jest sport osób z niepełnosprawnością i wizerunek sportowców z niepełnosprawnością w Internecie.

Pojmując cel jako przewidywany efekt działań badawczych [Guzik-Tkacz, Siegien-Matyjewicz 2012], jest nim poznanie i przybliżenie treści umieszczonych w Internecie, które dotyczą sportu oraz sportowców z niepełnosprawnością, określenie miejsca zjawiska sportu osób z niepełnosprawnością w Internecie oraz poznanie sposobu przedstawiania niepełnosprawnych sportowców w sieci. Poza tym, badania te podjęte są, jak każde inne, w celu zaspokojenia ciekawości świata [Lewicki, Błażejewski 2013]. 
Uznając, że problemy badawcze to pytania, jakie autor zadaje samemu sobie, a odpowiedź na nie możliwa jest w wyniku przeprowadzanych przez niego czynności badawczych [Muszyński 1971], formułuję je następująco: W jaki sposób przedstawiają w sieci sport osób niepełnosprawnych oraz samych siebie sportowcy z niepełnosprawnością? W jaki sposób prezentowany jest sport osób niepełnosprawnych oraz sportowcy z niepełnosprawnością w Internecie przez osoby trzecie?

Bez wątpienia, skoro w celach w zawartych w pracy określa się już obszar badań, jakim jest Internet, metodę badań można określić po prostu badaniami Internetu. W podstawach metodologicznych są one nazywane etnografią cyfrową, czy też netnografią. Badania te, jak sugeruje już sama nazwa, wywodzą się bezpośrednio z etnografii [Jemielniak 2013], co za tym idzie należałoby zastanowić się właśnie nad etnografią. Tę, rozumie się między innymi jako metodę badawczą, która pozwala na jak najbardziej spójne zebranie, przeanalizowanie i przedstawienie interesujących badacza danych. Wykorzystać można przy tym różne techniki pozyskiwania danych, a najczęściej są to: obserwacja (przede wszystkim uczestnicząca), wywiad czy też analiza dokumentów [Kostera 2003]. W niniejszej pracy najlepszym sposobem na przeprowadzenie badań byłaby analiza dokumentów, a konkretniej wytworów w Internecie wraz z obserwacją tego, co dzieje się w sieci.

Analizowane treści to przede wszystkim podawane na stronach informacyjnych wiadomości, wpisy na blogach, posty z portali społecznościowych, notki biograficzne z Wikipedii. Analizie poddana będzie nie tylko sama treść, ale także jej kontekst czasowy, a także to przez kogo została umieszczona (mam tu na myśli nie konkretną osobę, ale raczej czy została utworzona przez reprezentanta społeczeństwa pełno- czy niepełnosprawnego). Materiał wizualny-zdjęcia czy filmy stanowią swego rodzaju quasi-tekst i tym samym podlegać mogą takim samym zabiegom, jak sam tekst [Sztompa 2012].

\section{Organizacja i przebieg badań}

Zanim rozpocząłem właściwe badania, przystąpiłem do tzw. riserczu (researchu), tj. do przeszukania i wstępnego przeanalizowania przestrzeni internetowej. Przestrzenie w Internecie, na jakich się skupiłem, dobrałem ze względu na ich popularność oraz dostępność. Były to przede wszystkim portale społecznościowe (Facebook, Instagram), serwisy internetowe (np. YouTube), serwisy informacyjne, blogi itp. Posługiwałem się głównie wyszukiwarką Google. Przeglądarki internetowe działają tak, że dobierają bardzo szybko podobne, interesujące nas treści, co 
również było pewnym ułatwieniem. Bardzo często autorzy stron sami dodają odnośniki do innych, pozostających $w$ tej samej sferze.

Po takim rozeznaniu przystąpiłem do sporadycznych, później bardziej regularnych, ale nieustrukturalizowanych obserwacji tego, co dzieje się w przestrzeni sportu osób niepełnosprawnych w Internecie.

Etap ten zakończył się po paru miesiącach, po których nadszedł czas na ustrukturalizowanie swoich działań i selekcję zebranego wcześniej materiału, który został przeanalizowany według przyjętych założeń metodologicznych.

Paraolimpiada - parasportowcy - paraludzie? Sport osób z niepełnosprawnością w Internecie - analiza badań własnych

W pierwszej części analizy przedstawione i zinterpretowane zostaną treści, które wyrażają sposób przedstawiania sportowców niepełnosprawnych oraz sportu osób z niepełnosprawnością przez samych niepełnosprawnych. Mam tu na myśli tak osoby niepełnosprawne tworzące te treści, jak i szerzej - przestrzenie w sieci poświęcone niepełnosprawności, co nazwać można ( $w$ odniesieniu do niewirtualnej rzeczywistości) internetową społecznością (światem) niepełnosprawnych. Druga część będzie poświęcona treściom, które reprezentują przedstawienie zjawiska sportu i niepełnosprawnych sportowców przez osoby trzeciew wirtualnym „świecie pełnosprawnych".

Sport osób niepełnosprawnych i sportowcy z niepełnosprawnością $\mathrm{w}$ internetowej społeczności niepełnosprawnych

Doskonałym przykładem tej społeczności jest strona na portalu społecznościowym Facebook o nazwie Niepetnosprawni - Petnosprawni w Sporcie, która prowadzona jest przy portalu sportowym dla osób niepełnosprawnych parasportowcy.pl. Na facebookowej stronie znajdujemy miedzy innymi post dotyczący wygranych zawodów w skoku w dal dla osób niepełnosprawnych przez Karolinę Kucharczyk.

Informację zawartą $\mathrm{w}$ poście można nazwać typową sportową wiadomościach. Jest w niej podane imię i nazwisko zawodniczki, nazwa zawodów, wynik, wzmianka o rekordzie, który ta sama zawodniczka ustanowiła oraz gratulacje. Bardzo istotne z punktu widzenia tych badań jest to, że wzmianka o niepelnosprawności pojawia się jedynie w nazwie zawodów, wktórych pani Karolina brała udział. Nie jest także wskazane jaką niepełnosprawnością charakteryzują się inni ich uczestnicy ani sama zawodniczka. Przez to skupić się można przede wszystkim na jej wyniku i umiejętnościach sportowych. w poście widać ogromne emocje, a przede wszystkim podekscytowanie, już w pierwszych słowach: To się nazywa powrót w wielkim stylu! Wzmianka o rekordzie jest oddaniem szacunku dla jej do- 
robku (www.facebook.com/parasportowcy/photos/a.720164944799254.1073741833. 114213648727723/1071265286355883/?type.0.

$\mathrm{Na}$ portalu,do którego przynależy strona Niepetnosprawni - Petnosprawni w Sporcie, czyli na portalu parasportowcy.pl znajdujemy także wiele bardzo ciekawych artykułów dotyczących sportu osób z niepełnosprawnością. Przeanalizowany zostanie ten, dotyczący chyba najbardziej popularnego sportu w Polsce piłki nożnej, a konkretnie dotyczy on wygranej polskich piłkarzy w międzynarodowym turnieju blind football, czyli piłki nożnej dla osób niewidomych.

Artykuł zatytułowany jest Niewidomi Polscy Piłkarze Wygrali Międzynarodowy Turniej w Krakowie! $i$ już po samym tytule widać rangę tej drużyny i to jak ważną informację chce przekazać nam autor - nasza reprezentacja zdobyła pierwsze miejsce. We wstępie powtarza się informacja o zdobytym złotym medalu, zaznaczona jest dobra forma piłkarzy: Polacy, którzy w przekroju całych zawodów stracilizaledwie jednego gola..., a także podana jest informacja o tym, jak w ostatnim meczu wywalczyli mistrzostwo: ...w finałowym spotkaniu dzięki bramce Marcina Ryszki pokonali 1:0 reprezentację Irlandii i zasłużenie sięgnęli po końcowe zwycięstwo (www.parasportowcy.pl/niewidomi-polscy-pilkarze-wygrali-miedzynarodowy-turniej-wkrakowie0.

Dalsza część artykułu to przybliżenie czytelnikowi zasad blind footballu. Kolejną częścią jest wzmianka o samych rozgrywkach Bind Football Euro Challenge Cup, czyli turnieju, który wygrali Polacy, a odbył się on w Krakowie. Ostatnia najbardziej obszerna część artykułu to dość szczegółowa relacja z tego, jak przebiegała droga biało-czerwonych do zwycięstwa, kto został zdobywcą bramek oraz jakie drużyny rywalizowały ze sobą w walce o brąz.

Jak można zauważyć najważniejsza informacja pojawia się na początku dwukrotnie, a jest nią wiadomość o wygranych zawodach. Następnie po krótkim wstępie i objaśnieniu czytelnikowi jakiego sportu oraz turnieju dotyczy artykuł, jest on sprawozdaniem z poczynań piłkarzy na boisku. Nie ma w nim mowy o niewidomych czy niepełnosprawnych, poza przyjętą nazwą dyscypliny sportu oraz - co logiczne - opisanych po krótce zasadach gry. Przeważa w nim natomiast gra Polaków, strzelcy i wyniki.

Reprezentacja Polski w Rugby na Wózkach także prowadzi swoją oficjalną stronę na Facebooku i umieszcza tam wiele postów, zdjęć z udziałem polskich rugbistów. Chciałbym zaprezentować jedno ze zdjęć, które pojawiło się w poście zapraszającym do oglądania meczu w turnieju kwalifikacyjnym na Mistrzostwa Świata w Rugby na Wózkach 2018 (teraz już śmiało można pogratulować naszym rugbystom występu w Sydney!). 

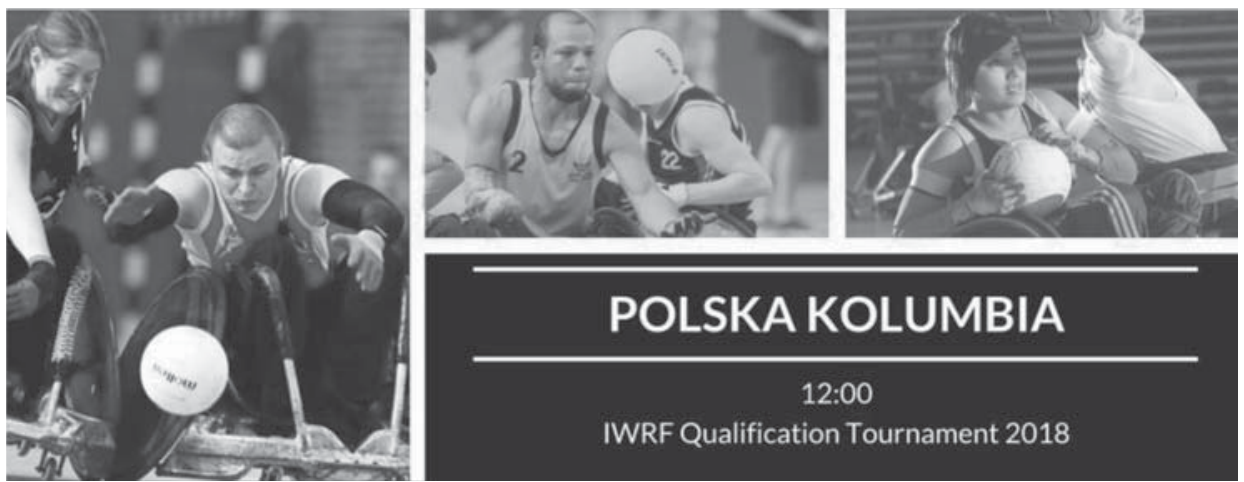

\section{POLSKA KOLUMBIA}

Fot. 1. Rugby na wózkach

Źródło: www.facebook.com/198990056780659/photos/a.473428446003484.116264.198990056780659/ 1867508223262159/?type $=3 \&$ theater

Trzy zdjęcia zebrane w kolaż przedstawiają zawodników rugby na wózkach. Na każdej z trzech fotografii jest po dwóch zawodników w trakcie gry. Zdjęcie pierwsze od lewej przedstawia walczących o nisko lecącą piłkę mężczyznę i kobietę, którzy wyciągają ręce w celu sięgnięcia piłki. Wyraźnie widać, że walka jest zacięta - wózek kobiety styka się z wózkiem mężczyzny, tak jakby waśnie w niego uderzyła, a na ich twarzach wyraźnie wypisany jest ich wysiłek. Mężczyzny prawa ręka jest po amputacji na wysokości łokcia. Drugie z kolei zdjęcie przedstawia mężczyznę w żółtej koszulce na wózku, który usiłuje złapać lecącą w jego kierunku piłkę, za którą schowany jest zawodnik w stroju niebieskim. Widać, jak bardzo napięte są wszystkie mięśnie, a zaciśnięte usta sugerują, że jest bardzo skupiony na lecącej piłce. Mężczyzna ma częściową protezę prawej ręki. Ostatnie ze zdjęć przedstawia kobietę w żółto-granatowym stroju, która siedzi na wózku i trzyma piłkę. Mężczyzna obok niej ma wyciągniętą rękę do góry, w kierunku zawodniczki, tak jakby próbował zablokować jej rzut. Kobieta patrzy w dal, szukając możliwości podania piłki.

Na każdych z tych zdjęć tworzących wspólną całość przedstawieni są zawodnicy niepełnosprawni, na wózkach. Jednak całość sprawia, ze zwraca się uwagę na te aspekty, które opisałem jako pierwsze, a więc na to co ci ludzie robią na zdjęciu, jakie emocje przedstawiają i w jakiej pozycji się znajdują. Dopiero na końcu, co celowo ujęte jest pod koniec opisu zdjęcia, zauważyłem na dwóch pierwszych zdjęciach, że mężczyźni są po amputacji. Sprawia to, po raz kolejny, że oglądający zauważa niepełnosprawność, bo nikt nie ukrywa, że ona jest, jednak skupia się na aspektach dynamiczno-emocjonalnych, które związane są ze sportem. Ogląda przez to po prostu sportowców (choć nadal ze świadomością, że posiadają nie- 
pełnosprawność; www.facebook.com/198990056780659/photos/a.473428446003484. 116264.198990056780659/1867508223262159/?type=3\&theater0.

Zbierając przedstawiony wyżej materiał, a także inne analizowane przeze mnie: $\mathrm{m}$. in. profil facebookowy polskich zimowych paraolimpijczyków, biathlonistów, blog poświęcony różnym sportom osób z niepełnosprawnością, można stwierdzić duże podobieństwo we wszystkich analizowanych treściach. Wyraża się ono przede wszystkim w sposobie przedstawiania sportu niepełnosprawnych oraz osoby z niepełnosprawnością, jako sportowca, a raczej sportowca z niepełnosprawnością. Ta subtelna, wydawałoby się, różnica przedstawia tak naprawdę meritum. W przestrzeni Internetu pozostającej wokół niepełnosprawności i sportu osób niepełnosprawnych, ten właśnie sport pozostaje sportem samym w sobie, a sportowiec z niepełnosprawnością jest przede wszystkim sportowcem. Być może brzmi to jak pleonazm, jednak są to najprostsze i zarazem jedyne słowa, które mogą dokładnie wyrazić wniosek, płynący z tych treści. Fakt ten, bynajmniej, nie oznacza, że ktokolwiek udaje, że tej niepełnosprawności nie ma i próbuje ją zatuszować. Ona zostaje gdzieś w tle, bo nie jest najistotniejsza.

Sport osób niepełnosprawnych i sportowcy z niepełnosprawnością przedstawiani przez osoby trzecie - w internetowym "świecie pełnosprawnych"

Igrzyska Olimpijskie i Paraolimpijskie odbywają się co cztery lata i uczestniczą w nich najlepsi zawodnicy z całego świata. Są uważane za zawody o najwyż- szej randze. Zimowe Igrzyska Olimpijskie miały swój oficjalny profil na portalu społecznościowym Instagram o nazwie PyeangChang2018. Wystartował on przed rozpoczęciem Igrzysk i działa do dziś. Początkowo pojawiały się na nim wpisy dotyczące organizacji Igrzysk, fotorelacja $\mathrm{z}$ inauguracji, informacje dodatkowe związane bezpośrednio lub pośrednio z Olimpiadą i zawodnikami. Z niecierpliwością czekałem na zakończenie Igrzysk Olimpijskich, aby sprawdzić, jak profil będzie działał w czasie Igrzysk Paraolimpijskich. Ku mojemu zdziwieniu, nic w jego funkcjonowaniu się nie zmieniło i zachował dokładnie taką samą formę, jak podczas zawodów dla osób pełnosprawnych. Stał się także oficjalnym profilem Igrzysk Paraolimpijskich. W czasie Paraolimpiady pojawiały się zatem zdjęcia sportowców wraz z notką o medalistach w języku angielskim i chińskim (podana dyscyplina, nazwiska, kraje, wyniki). Informacja ta nie była okraszona żadnym zbędnym tekstem ani dodatkowymi informacjami - tak samo jak robiono to podczas Zimowych Igrzysk Olimpijskich - suche (choć, jak ważne, informacje). Zdjęcia do nich były wyraźnie dobrane tak, by ukazać możliwy sposób prezentowania sportowców z niepełnosprawnością - bez ukazywania niepełnosprawności, lecz z jej lekkim zaakcentowaniem, z widocznymi atrybutami osoby niepełnospraw- 
nej. Ukazując przy tym przede wszystkim sportowców, reprezentantów danego kraju, Olimpijczyków. Zasada ta zachowana jest także przy wszystkich zdjęciach widocznych na profilu (www.instagram.com/pyeongchang2018/0.

Nie można zapomnieć o wielkim sukcesie „Naszych" na Igrzyskach. Na portalu sportowym prowadzonym przez Wirtualną Polskę - sportowefakty.pl można znaleźć artykuł dotyczący zdobycia medalu przez Polaka na paraolimpiadzie. Sam tytuł oraz nagłówek artykułu wydaje się być typowy dla tego typu informacji mówiących o osiągnięciach sportowych naszych rodaków. W tytule zawarto krótką, najważniejszą informację o tym, że Polska wywalczyła pierwszy medal. W nagłówku znajduje się rozszerzenie informacji podanej wyżej - imię i nazwisko zawodnika oraz dyscyplina sportowa, w której brał udział. Dalsza część artykułu wygląda także bardzo typowo: opisany jest typ zawodów, konkurencja, zmagania reprezentanta i wyniki. Bardzo istotne są jednak same okoliczności związane z jego ukazaniem. Jest to ważne, ponieważ o występach naszych zawodników na Igrzyskach Paraolimpijskich na stronach wykraczających poza środowisko osób niepełnosprawnych pisze się przede wszystkim wtedy, kiedy po ośmiu latach przerwy zdobędą medal, nie komentując szczególnie pozostałych występów. To dość nadzwyczajna sytuacja chociażby ze względu na rangę zawodów, jakimi są Igrzyska. Poza tym, że jest to jedna z niewielu informacji dotyczących występu naszych zawodników w PyeongChang, nie była ona wyszczególniona na portalu, jako jedna $\mathrm{z}$ ważniejszych, a znajdowała się $\mathrm{w}$ grupie informacji dotyczących innych występów i zawodów odbywającym się w tym czasie.

Jeden z artykułów należący do tej samej grupy także dotyczył sportowca $\mathrm{z}$ niepełnosprawnością. Ma on jednak zupełnie inny charakter. Można to zauważyć na podstawie samego tytułu: Jest niewidoma, przeżyła fatalny wypadek. Millie Knight bohaterkq Wielkiej Brytanii (www.sportowefakty.wp.pl/narciarstwo-alpejskie). Sam tytuł sugeruje, że jest bohaterką bez względu na to, co udało jej się osiągnąć, ponieważ jest osobą, która przeżyła wypadek - autor podkreślił, że był on fatalny - oraz ze względu na jej niepełnosprawność wzroku. Dlatego też, mimo niepodważalnego sukcesu - Millie zdobyła dwa srebrne medale na Igrzyskach, jakim jest zdobycie medali olimpijskich można odczuć, że jest ona gloryfikowana, mimo wszystko, nad wyraz, ze względu na bycie osobą niewidomą (www.sportowefakty. wp.pl/narciarstwo-alpejskie).

Można zaryzykować stwierdzenie, że prawie każdy, lub nawet każdy użytkownik Internetu zna Wikipedię. Czym ona jest określa doskonale jej slogan: „Wolna encyklopedia, którą każdy może redagować" (pl.wikipedia.org). Skoro każdy może ją redagować i jest swego rodzaju encyklopedią, można także stwierdzić, że powinna zawierać szereg informacji z bardzo różnych dziedzin. $Z$ pewnością zawiera informacje o sportowcach z niepełnosprawnością. Informacje te nie są prezentowane jednoznacznie. Jest wśród nich grupa fenomenów i niepełnospraw- 
nych, jako nadzwyczajnych ludzi, która pozostaje w zbliżonym klimacie do artykułów z WP. Przykładem tego są notki o Natasy Kovacevic oraz Michael'u May. Natasa jest koszykarką, która na Wikipedii słynie przede wszystkim z tego, że jest pierwszą koszykarką po amputacji, grającą w profesjonalnej drużynie koszykarskiej (pl.wikipedia.org/wiki/Nata\%C5\%A1a_Kova\%C4\%8Devi\%C4\%87). Wiadomości dotyczące Michaela skupiają się głównie na wybuchu, który przeżył i utracie wzroku w tym wypadku, a także o próbach jego odzyskania i pionierskich zabiegach, które miały mu w tym pomóc. Gdzie tu sport? Otóż pan May był brązowym medalistą paraolimpijskim i pobił rekord prędkości zjazdu na nartach przez osobę niewidomą, co wydaje się nader istotne w życiorysie osoby, którą na wstępie opisuje się jako sportowca (pl.wikipedia.org/wiki/Mike_May). Wzmianki te giną jednak pośród informacji o wybuchu i zabiegach. Przykładem idealnie wyważonej biografii w Wikipedii jest bez wątpienia notka o Justynie Kozdryk. Nagłówek stanowi przedstawienie Justyny Kozdryk, jako polskiej sztangistki, która zdobywała liczne medale, $m$. in. na paraolimpiadzie. Nie jest tu zaznaczona niepełnosprawność zawodniczki, jednak wspomnienie o paraolimpiadzie sugeruje, że jest ona osobą z niepełnosprawnością. Potwierdza się $\mathrm{w}$ to $\mathrm{w}$ pierwszym zdaniu Życiorysu, które informuje o achondroplazji zawodniczki i jej wzroście związanym z chorobą. Autor dostarcza czytelnikowi także wiedzy na temat ukończonych przez nią studiów oraz tego, czym zajmuje się poza sportem. Jest to jednak krótka wzmianka we wstępie. Resztę stanowi opis jej kariery sportowej. Końcowe zdanie mówi o zdobyciu Złotego Krzyża Zasług, jednak nie jest podany powód otrzymania tego odznaczenia(pl.wikipedia.org/wiki/Justyna_Kozdryk). Jest to zatem typowa, wręcz wzorowa notka biograficzna sportowca.

Nieco trudniej znaleźć wspólny mianownik wśród materiałów znajdujących się w przestrzeni tworzonej przez osoby trzecie. Sposób przekazywania informacji o sportowcach niepełnosprawnych i sporcie osób z niepełnosprawnością jest różny. Wspólnym mianownikiem może być fakt, że jest on zdecydowanie inny niż $\mathrm{w}$ sferze tworzonej przez osoby z niepełnosprawnością. Wyjątek stanowi profil Zimowych Igrzysk Olimpijskich na Instagramie, który ukazywał przede wszystkim sport, a niepełnosprawność była tam na drugim, bądź kolejnym miejscu i pojawiała się tylko i wyłącznie ze względu na charakter prezentowanych dyscyplin. Dziać się tak mogło za sprawą tego, że profil ten można by zaliczyć do miejsca zawieszonego pomiędzy światami sportu niepełnosprawnych a sportu w ogóle, ponieważ był on zarówno profilem Zimowych Igrzysk Olimpijskich, ale także stał się oficjalnym profilem Zimowych Igrzysk Paraolimpijskich. Pozostałe treści charakteryzuje przede wszystkim zupełne odwrócenie stosunku niepełnosprawności do sportu. W nich to zazwyczaj niepełnosprawność staje się tą ważniejszą, a sport pozostaje w jej tle. Ważne są też okoliczności, w których pojawiały się artykuły, motywacje dla których powstały i to czego dotyczyły. W głównej mierze do- 
tyczą one pewnej sfery niezwykłości i fenomenu, a także pokazania osiągnięć życiowych osób z niepełnosprawnością, pokonujących wszelkie spotkane ich niedogodności losu, a nie osiągnięcia sportowe.

\section{Zakończenie}

Analizowane treści zostały podzielone na dwie grupy, które wynikały z postawionych wcześniej pytań badawczych. Nie da się ukryć, że grupy te reprezentują zróżnicowane względem siebie podejścia do przedstawiania sfery sportu osób z niepełnosprawnością, a co za tym idzie także samych niepełnosprawnych sportowców. Odwołując się do teoretycznych rozważań w mojej pracy, uważam, że sport osób niepełnosprawnych reprezentowany w Internetowej przestrzeni osób z niepełnosprawnością jest tym, który pozwala przeplatać świat pełno- i niepełnosprawnych, gdyż występuje w zbliżonych do siebie formach. Jest to sport, którego jedynie dodatkowym celem jest poprawa funkcjonowania $w$ sferze fizycznej oraz społecznej. W przypadku treści przedstawianych przez osoby trzecie, bywa on prawie pozbawiony swojego sportowego charakteru, a intencja przekazu zostaje odwrócona w taki sposób, że sport jest jedynie tłem, bądź narzędziem służącym do zaprezentowania osoby niepełnosprawnej. Z kolei, niepełnosprawność sportowców w pierwszej grupie treści wydaje się być ukazana w taki sposób, iż bliższa jest społecznemu modelowi niepełnosprawności, czyli jako zjawisko, które pojawia się w społeczeństwie, nie będące głównym czynnikiem charakteryzującym osobę niepełnosprawną. Treściom $\mathrm{w}$ drugiej grupie bliżej natomiast do modelu funkcjonalnego - niepełnosprawność jawi się tutaj utrudnieniem $w$ tak zwanym normalnym życiu, z którym prezentowane osoby uprawiające sport borykają się, by móc funkcjonować, jak pozostała część społeczeństwa. Kiedy im się to uda, stają się jednak zdecydowanie kimś więcej niż jedynie uczestnikami życia społecznego, czyli - jak w przypadku tej pracy - również sportowego.

Odpowiedź na zadane w tytule pytanie nie jest jednoznaczna i różnić się będzie w każdej z grup. Moim zdaniem, prezentowane treści pojawiające się $\mathrm{w}$ „świecie niepełnosprawnych" dotyczą raczej olimpiady, sportowców i ludzi, a nie paraolimpiady, parasportowców i paraludzi w wyjaśnionym wcześniej rozumieniu przedrostka "para”. Nie ma w nich choćby wzmianki, która sugerowałaby, że sportowcy z niepełnosprawnością są udającymi "tych prawdziwych", niby-sportowcami, a sport przez nich uprawiany jest quasi-sportem.

W drugiej grupie jest to bardziej złożone. Odbiór treści wiąże się z wydźwiękiem przedrostka "para-", jaki sugerowany był w części teoretycznej pracy. Sportowcy z niepełnosprawnością prezentowani są, jako niby sportowcy, którzy upra- 
wiają sport jedynie po to, by po pierwsze ukazać światu, że potrafią coś osiągnąć, a po drugie - jest to forma rehabilitacji społecznej, a gdzieś daleko w tle dopiero piękno sportu, które zdecydowanie traci swoją wartość. Paraolimpiada jest zatem jedynie przestrzenią w której niepełnosprawni niby-sportowcy mogą ze sobą rywalizować. Nie oznacza to, paradoksalnie, że odbiera się im zasługi ze względu na udział w nich. Nie odbiera się im przy tym człowieczeństwa. Stają się parasportowcami na paraolimpiadzie, jednak nie są paraludźmi. Często dzieje się wręcz odwrotnie - przestawiani są jako hiperludzie, którzy dzięki nadzwyczajnej mocy pokonali wszelkie przeciwności, by móc osiągnąć coś, co nie jest w zasięgu niejednego w pełni sprawnego człowieka. Czy pozostanie człowiekiem w pełni nie oznacza, że jednocześnie zajęcie się profesjonalnym sportem czyni sportowcem, a nie jedynie - „para"? Czy zatem, sportowiec nie bierze udziału w olimpiadzie, a nie paraolimpiadzie? Treści prezentowane przez osoby trzecie są niedoskonałe, jednak widać w niektórych przykładach powolne podążanie za zmianami dokonującymi się w polu dociekań i badań nad niepełnosprawnością.

Badanie te ukazują, jak ważnym i potężnym medium jest Internet. Cały świat, w którym na co dzień żyjemy zdaje się być w nim przekalkowany. Dokładnie tak samo dzieje się z obszarem zainteresowań pedagogiki specjalnej. Główny nurt, za którym podążają pedagodzy specjalni kreowany jest właśnie przez osoby z tak zwanej branży i samych niepełnosprawnych. Za nimi podąża reszta społeczeństwa, która powoli „oswaja się" z pojawiającą się wśród niej niepełnosprawnością.

\section{Bibliografia}

Guzik-Tkacz M., Siegień-Matyjewicz A. (2012), Leksykon terminów metodologicznych. Nauki pedagogiczne i pokrewne, Wydawnictwo Akademickie Żak, Warszawa.

Jemielniak D. (2013), Netnografia, czyli etnografia wirtualna - nowa forma badań etnograficznych, „Prakseologia”, nr 154.

Kirenko J. ( 2006), Oblicza niepetnosprawności, Wydawnictwo Wyższej Szkoły Społeczno-Przyrodniczej, Lublin.

Kirenko J., Sarzyńska E. (2010), Bezrobocie, niepetnosprawność, potrzeby, Wydawnictwo Uniwersytetu Marii Curie-Skłodowskiej, Lublin.

Koper M., Tasiemski T. (2013), Miejsce sportu w rehabilitacji osób niepetnosprawnych fizycznie, „Niepełnosprawność - Zagadnienia, problemy, rozwiązania”, t. 2, nr 8.

Kostera M. (2003), Antropologia organizacji: Metodologia badań terenowych, Wydawnictwo Naukowe PWN, Warszawa.

Kulesza E.M., Marcinkowska B. (2004), Definicje, skala i dynamika zjawiska niepetnej sprawności [w:] Piekut-Brodzka D., Kuczyńska-Kwapisz J., Pedagogika specjalna dla pracowników socjalnych, Akademia Pedagogiki Specjalnej im. Marii Grzegorzewskiej, Warszawa.

Lewicki Cz., Błażejewski W. (2013), Metody i techniki gromadzenia, opisu oraz analizy wyników badań empirycznych w naukach społecznych ze szczególnym uwzględnieniem pedagogiki, Wy- 
dawnictwo Państwowej Wyższej Szkoły Techniczno-Ekonomicznej im. ks. Bronisława Markiewicza w Jarosławiu, Jarosław.

Maszczak T. (1998), Kultura fizyczna wedukacji osób niepetnosprawnych [w:] Pedagogika specjalna. Wobec potrzeb teraźniejszości i wyzwań przyszłości, M. Chodakowska (red.), Wydawnictwo Uniwersytetu Marii Curie-Skłodowskiej, Lublin.

Muszyński H. (1971), Wstęp do metodologii pedagogiki, Wydawnictwo Naukowe PWN, Warszawa.

Papiernik M. (2011), Sytuacja życiowa osób niepetnosprawnych mieszkających w Polsce i czynniki ja determinujące, Unic, Warszawa.

Para-(hasło) [w:] Drabik L., Kubiak-Sokół A., Sobol E., Słownik języka polskiego PWN, Wydawnictwo Naukowe PWN, Warszawa 2017.

Pawlikowska-Piechotka A. (2016), Przestrzeń sportu, rekreacji i turystyki bez barier, Wydawnictwo AWF Warszawa, Warszawa.

Sadowska S. (2005), Ku edukacji zorientowanej na zmianę społecznego obrazu osób niepetnosprawnych, Wydawnictwo Edukacyjne Akapit, Torun.

Sztompka P. (2012), Socjologia wizualna. Fotografia jako metoda badawcza, Wydawnictwo Naukowe PWN, Warszawa.

Wiliński M. (2010), Modele niepetnosprawności: indywidualny - funkcjonalny - społeczny [w:] Diagnoza potrzeb i modele pomocy dla osób z ograniczeniami sprawności, A.I. Brzezińska, R. Kaczan, K. Smoczyńska (red.), Wydawnictwo Naukowe Scholar, Warszawa.

\section{Netografia}

pl.wikipedia.org [dostęp: 07.05.2018]

pl.wikipedia.org/wiki/Justyna_Kozdryk [dostęp: 07.05.2018]

pl.wikipedia.org/wiki/Mike_May [dostęp: 07.05.2018]

pl.wikipedia.org/wiki/Nata\%C5\%A1a_Kova\%C4\%8Devi\%C4\% 87[dostęp: 07.05.2018]

www.cbos.pl/SPISKOM.POL/2013/K_129_13.PDF [dostęp: 01.05.2018]

www.facebook.com/198990056780659/photos/a.473428446003484.116264.198990056780659/

1867508223262159/?type=3\&theater [dostęp: 07.05.2018]

www.facebook.com/parasportowcy/photos/a.720164944799254.1073741833.114213648727723/

1071265286355883/?type [dostęp: 13.05.2018]

www.instagram.com/pyeongchang2018/ [dostęp: 07.05.2018]

www.paralympic.org.pl [dostęp: 21.01.2018]

www.paralympic.org/rio-2016 [dostęp: 20.01.2018]

www.parasportowcy.pl/niewidomi-polscy-pilkarze-wygrali-miedzynarodowy-turniej-w-

krakowie [dostęp: 07.05.2018]

www.polskatimes.pl/strefa-biznesu/wiadomosci/a/juz-niemal-70-proc-polakow-deklaruje-

ze-regularnie-uprawia-sport,12561418/ [dostęp: 01.05.2018]

www.pzsnstart.eu/hokej-na-sledgach [dostęp: 21.01.2018]

www.sportowefakty.wp.pl/narciarstwo-alpejskie [dostęp: 16.03.2018] 